\title{
The Lexicalization Patterns of Old Chinese Motion Verbs and the Manner/ Result Complementarity
}

\author{
Lei Qiu \\ School of Foreign Languages, Huaiyin Normal University, China
}

Copyright $(2017$ by authors, all rights reserved. Authors agree that this article remains permanently open access under the terms of the Creative Commons Attribution License 4.0 International License

\begin{abstract}
Rappaport Hovav and Levin[1,2] propose the manner/result complementarity (MRC), which predicts the non-existence of verbs lexicalizing both manner and result at a time. Scholars [3, 4] argue against the MRC as a general lexical principle governing the lexicalization patterns of verbs by naming verbs which seem to encode both meaning components simultaneously. One type of counterexample verbs are based on the lexicalization properties of typologically different languages. Following Slobin [5], Shi and $\mathrm{Wu}$ [6] suggest that manner and result meaning components exhibit complementary distribution in satellite-framed languages but not verb-framed languages. Though Modern Chinese is generally classified as a satellite-framed language, Old Chinese is regarded as a verb-framed language and the lexicalization patterns of Old Chinese motion verbs are also subjected to controversy. Drawing evidence from motion verbs in Old Chinese, this study tries to answer whether the MRC constrains the possible lexicalization patterns of motion verbs in verb-framed languages. Detailed analysis indicates that though typologically different languages may use morphosyntactic devices specific to the language to differentiate verbs falling into different ontological categories, Old Chinese motion verbs conform to the MRC hypothesis.
\end{abstract}

Keywords Manner/ Result Complementarity, Motion Verbs, Lexicalization Patterns

\section{Introduction}

Across languages based on what conceptual components a verb may include in its lexical meaning, motion verbs can be roughly divided into ontologically two different types: manner of motion verbs, which specify how the motion is carried out and path or directed motion verbs, which describe the trajectory over which an entity moves with respect to a reference object $[7,2]$. With different lexical meaning components, the two types of motion verbs also exhibit distinct grammatical behaviors. Based on the correlation between lexicalized meaning components in motion and change of state verbs and their corresponding grammatical behaviors, Rappaport Hovav and Levin[1, 2] propose a lexical constraint that a verb lexicalizes only one type of meaning component at a time, manner or result, and dub it as manner/result complementarity (MRC). As to motion verbs, path of motion is considered to be a subtype of result with respect to the spatial property of an entity and thus according to this lexical constraint, manner and path information cannot be simultaneously encoded. Ever since Rappaport Hovav and Levin's proposal of MRC, it has been challenged by researchers who question the validity of the MRC as a general lexical principle governing the lexicalization patterns of verbs in languages. One type of the counterarguments is related to the specific lexicalization properties of motion verbs in languages falling into different typological groups: verb-framed or satellite-framed languages [8, 7]. For example, Following Slobin [5], Shi and $\mathrm{Wu}$ [6] suggest that the lexicalization of manner and path in motion verbs only exhibits a complementary distribution in satellite-framed languages, but not in verb-framed languages. Slobin [5] points out that in spite of the major lexicalization patterns of conflating either manner or path in verbs across languages, some languages do have minor lexicalization patterns which conflate both manner and path with motion in verbs, and this kind of lexicalization pattern is in particular attested in some verb-framed languages. However, Slobin only names some isolated motion verbs such as Turkish motion verb tirmanmak 'climb up' which he assumes to violate the lexical constraint MRC, but he does not discuss the lexical meaning of motion verbs under the tenets of MRC hypothesis systematically. To solve the controversy, a systematic and comprehensive investigation aiming at revealing the actual lexicalization patterns of motion verbs in certain verb-framed language and finding the evidence for or against the MRC hypothesis is necessary.

Though Modern Chinese is generally regarded as a satellite-framed language $[7,9,10$,$] , researchers also argue$ 
that Old Chinese ${ }^{1}$ is typologically distinct from Modern Chinese and it should be classified as a verb-framed language $[11,12,6]$. Furthermore, while researchers have argued that the lexicalization patterns of motion verbs in Modern Chinese conform to the MRC hypothesis [13, 14], it is not necessarily true in Old Chinese, since Chinese has undergone radical changes as to its phonological systems, lexical resources and morphosyntactic structures since Old Chinese period. Though many verbs in Old Chinese share the same graphic and phonetic representations with their counterparts in Modern Chinese, some of them have completely changed their grammatical category and thus cannot be used as verbs in Modern Chinese (e.g. 之 $z h \bar{l}$ 'go' 适 shi 'go' 如 rú 'go'). Though some other verbs still keep their verbal nature, the syntactic constructions in which they may appear are very different. For example, while the verb 走 zǒu 'walk' in Modern Chinese cannot be immediately followed by locative nouns to indicate the goal of motion as can be seen in (1a), it is completely acceptable in Old Chinese, as shown in (1b)

\author{
(1) a. *走 学校 \\ zǒu xuéxiào \\ walk school \\ walk to school' (Intended meaning) \\ b. 奉 君 以走固宫 \\ fèng jūn y̌̃ zǒu gùgōng \\ serve king CONJ run Gu Palace \\ 'serve the king to run to the Gu Palace'
}

(Zuǒzhuàn Xiāng Gōng 23rd Year)

In addition, as mentioned above, researchers suggest the lexicalization patterns in verb-framed languages may not adhere to the MRC hypothesis. Concerning Old Chinese, $\mathrm{Ma}[12]$ and Shi and $\mathrm{Wu}[6]$ argue that Old Chinese allows a type of semantically synthetic verbs which lexicalize both manner and path meaning simultaneously. Upon these controversies, motion verbs in Old Chinese deserve independent investigation. In light of the MRC hypothesis, the present study is to further uncover the lexicalization patterns of Old Chinese motion verbs trying to provide direct empirical evidence for or against the MRC hypothesis.

This paper is structured as follows: Section 2 explicates the main tenets of the MRC hypothesis. Some background information of Old Chinese as to its general typological properties and motion events encoding is delineated in Section 3. Section 4 explains the research methods and relevant data used in present study. Section 5 presents a detailed discussion of the lexicalization patterns of motion verbs in Old Chinese. Section 6 concludes the whole study.

1 Old Chinese is a language used from the Warring States Period (500$200 \mathrm{BC})$ to the Han Dynasty (206 BC-220 AD).

\section{The MRC as a Lexical Constraint}

It has long been observed that verbs may appear in a range of syntactic contexts exhibiting varied grammatical behaviors. As illustrated by Rappaport Hovav and Levin [1] (1998), the manner of motion verb sweep allows unspecified object (2a), can take objects with different second predicate as $(2 b)$ and $(2 c)$.

(2) a. Terry swept.

b. Terry swept the crumbs into the corner.

c. Terry swept the leaves off the sidewalk. p 97 [1]

Researchers $[15,1]$ also note that variation illustrated in (2) is not only available to individual verbs but also to the entire class of verbs. For example, verbs involving contact through motion such as scrub and wipe all shares the same pattern of variation as sweep. However, verbs from other semantic group (e.g. change of sate verbs) do not permit the same pattern of variation. For instance, verbs such as break, crack, open do not allow the variation illustrated in (1). It can be seen from the ungrammaticality of sentences in (2), when the verb break involves relevant alternations.

(3) a. *Kelly broke.

b. *Kelly broke the dishes into a pile.

c. *Kelly broke the dishes off the table. P 97 [1]

The variation that a verb may or may not involve seems to be regulated in a principled way. Assuming that a verb's grammatical behavior is largely determined by its lexical semantics, Rappaport Hovav and Levin[1,2] give an account for this phenomenon based on the lexicalized meaning in verbs. According to them, the argument realization of a verb is determined by event structure decomposition. Based on the nature of concept a verb lexicalizes, it has a basic ontological category such as manner or result, which in turn determines what kind of event schema the verb may involve and how it integrates into the schema. Verb roots of different ontological categories are associated with event schema in distinct ways. For example, a manner verb such as sweep prototypically involves an event schema featuring activity as (4a) and the manner root integrates into the event schema as modifier of the primary predicate ACT as in (4b). In contrast, an externally causative result verb such as break involves an accomplishment event as in (4c) and the result root integrates into the event schema as the argument of the primary predicate BECOME as in (4d).

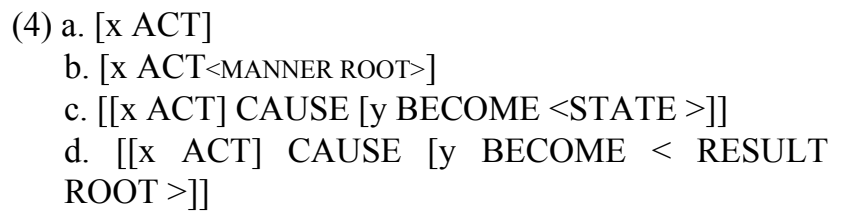

Thus associated with simple event structure, manner verbs are more flexible in argument alternations allowing unspecified and unsubcategorized objects. In contrast, 
involving complicated event structure, result verbs show more rigid grammatical behaviors generally prohibiting unspecified and unsubcategorized objects.

Besides their contrastive grammatical behaviors, another important difference between the two types of verbs is reflected through their distinct lexicalized meaning. Assuming each root has only one position in an event schema and manner, and since result verbs have distinct positions, Rappaport Hovav and Levin [1, 2] generalize that manner and result meaning components cannot be lexicalized simultaneously in a verb root at a time. That is what the MRC hypothesis predicts: the manner and result meaning components are in complementary distribution.

The MRC hypothesis is also independently supported by the distinct semantic notions the two types of verbs involve. Drawing on scalar semantics $[15,16]$, Rappaport Hovav and Levin [2] suggest that manner and result verbs also involve different scalar structures: result and manner verbs are associated with scalar and non-scalar changes respectively. In both change-of-state and motion domains result verbs involve scalar changes, as they lexicalize change in the value of some scalar attribute, while manner verbs lexicalize non-scalar changes which are complex and cannot be characterized by an ordered set of values of a single attribute. Relevant to the different scales the two types of verbs involve, they are also attested to demonstrate contrastive aspectual features. While manner verbs are generally atelic activity verbs, result verbs associated with two-point scales are necessarily punctual and telic. Even result verbs involving multiple-point scales can be interpreted telically without supporting context [18].

However, it is worth noting that the MRC only constrains the lexicalized meaning components in verbs. Rappaport Hovav and Levin[1,2] point out that besides lexicalized meaning components, verbs are often associated with pragmatic inference from conventional use of verbs, but pragmatic meaning is irrelevant with the MRC hypothesis. For example, as illustrated by Rappaport Hovav and Levin [2]. The verb wipe in its conventional use often brings about a result that something becomes clean, but the result is not entailed in the lexical meaning of the verb, and rather the verb only lexicalizes a meaning component of manner. In order to check the validity of the MRC it is essential to differentiate the lexical meaning from the pragmatic meaning drawing from the contexts. In this study, following Rappaport Hovav and Levin [2], the lexicalized meaning of a verb is the meaning component that is constant in all uses of the verb across contexts.

Though the MRC hypothesis is reflected in lexicalized meaning and grammatical behaviors in both change of state and motion domain, the present study mainly focuses on motion verbs in Old Chinese, since with respect to lexicalization patterns of motion verbs researchers especially doubt the validity of the MRC in verb-framed language such as Old Chinese. Before a detailed analysis of Old Chinese motion verbs, the next section will first introduce some typological properties of Old Chinese and the encoding of motion events in general.

\section{Background of Old Chinese}

\subsection{Key Typological Characteristics of Old Chinese}

The history of Chinese language is featured by an evolution from monosyllabic to disyllabic words $[19,20]$. In Modern Chinese disyllabic words count most part of the lexicon, but in Old Chinese most words are believed to be monosyllabic. In Old Chinese period, only about $20 \%$ of the lexicon is disyllabic [20]. The monosyllabic feature of Old Chinese verbs can be best attested by the contrast between their morphological forms in Old Chinese and their corresponding Modern Chinese translation in (5).

\section{(5) a. 郑人 袭 胡, 取之 zhèng rén xí hú qǔ zhī} Zheng.State people attack Hu.State capture it 'The State of Zheng attacked and captured the State of $\mathrm{Hu}$ '

(史记老子韩非子列 Shǐjì Lăozi Hánfēi lièzhuàn)

\section{b. 郑国人 袭击胡国，把它 夺取了 zhèngguó rén xíjī húguó bă tā duóqŭ le Zheng.State people attack Hu.State BA it capature ASP 'The State of Zheng attacked and captured the State of $\mathrm{Hu}$}

(史记全译 Shǐjì Quányì by Yang Yanqi)

In (5a) verbs expressing the meaning 'attack' and 'capture' are both represented by monosyllabic verbs 袭 $x i$ 'attack' and 取 qú 'capture' in Old Chinese, but their Modern Chinese counterparts are both represented as disyllabic verbs 袭击 xiji ' 'attack' and 夺取 duóqǔ 'capture' in $(5 b)$.

Different from Modern Chinese, Old Chinese is also reported to have more complicated phonological system and morphological derivation system. Wang [19] observes that verbs with the same pronunciation in Modern Chinese may show contrastive features in initials, finals or tones in Old Chinese. More importantly, words in Old Chinese are attested to be derivable by changing the phonetic features of words. This process resembles some phonologically featured word derivation process in English, if the verb 'bleed' is considered to be derived from the noun 'blood' by changing the vowel or the verb 'record' is derived from the noun 'record' by changing the stress placement of the word [21]. Some of the attested phonological derivation processes in Old Chinese are voicing, changing vowel quality and tone alternation [22, 23, 19, 24-26]. Among them, tone alternation is the most clearly documented derivation process, which is 'the use of a change of tone to create a new word related in meaning to base word' [20]. In this process a new word is derived from a base word by 
changing its original tone which is one of the three tones 平声 píngshēng 'level tone,' 上声 shàngshēng 'rising tone' and 入声 rùshēng 'entering tone' to the forth tone 去声 qùshēng 'departing tone'. However, it is worth noting that the relationship between such tonally derived word pairs is not fixed. They may be contrastive with each other by differences in varied semantic or grammatical properties. Some commonly documented derivation processes through tone alternation involve noun to verb, intransitive to transitive or causative derivation. Example word pairs involving derivation through tone alternation are given in Table 1. Most of the examples are from Packard [21], with some words discussed by Sun also included. The phonetic forms of the example words are modified from the sources for consistency. The reconstruction of the pronunciation of Old Chinese is based on Guo [27], and is transcribed into International Phonetic Alphabet. As the tones of Old Chinese are not exactly the same as those of Modern Chinese, instead of using tone markings on Pinyin, researchers studying Old Chinese phonology usually adopt a different transcription system for tones in Old Chinese for accuracy. The present study following Sun[28] represents the four tones by adding half circles on the four sides of the word: $\mathrm{c}$ 平 (level tone), ${ }^{\mathrm{c}}$ 上 (rising tone), 入。(entering tone), and 去 $^{\circ}$ (departing tone).

Table 1. Word pairs involving derivation via tone alternation

\begin{tabular}{|c|c|c|c|}
\hline Base word & Gloss & $\begin{array}{c}\text { Departing tone } \\
\text { derived word }\end{array}$ & Gloss \\
\hline 冠 ${ }^{\mathrm{c}}$ kuan & 'cap' & 冠 kuan ${ }^{\circ}$ & 'to cap' \\
\hline 王 $^{c}$ yı̌a & 'king' & 王 yǐan ${ }^{\circ}$ & 'be king \\
\hline 饭 ${ }^{\mathrm{c}}$ bǐwan & 'eat' & 饭 bǐwan ${ }^{\circ}$ & 'food' \\
\hline 好 ${ }^{\mathrm{c}} \mathrm{x} ә \mathrm{u}$ & 'pretty' & 好 $\mathrm{x}^{\circ}{ }^{\circ}$ & 'to love' \\
\hline 高 c kau & 'high' & 高 $\mathrm{kau}^{\circ}$ & 'height' \\
\hline 受 ${ }^{\mathrm{c}}$ Zı̌ou & 'receive' & 授 zĭou ${ }^{\circ}$ & 'give' \\
\hline 下 ${ }^{c}$ yea & 'go down' & 下 yea ${ }^{\circ}$ & 'lower' \\
\hline 上 ${ }^{\mathrm{c}}$ zĭan & 'ascend' & 上 zĭay ${ }^{\circ}$ & $\begin{array}{l}\text { 'above, } \\
\text { top' }\end{array}$ \\
\hline
\end{tabular}

It can be seen in the table the tone derivation process involves various grammatical functions such as from nouns to verbs (e.g, 冠, 王), from adjectives to nouns (e.g., 高), or from intransitive to transitive verbs (e.g., 下). The Chinese characters representing the base and derived forms are usually the same or differ only minimally, with the same component reflecting their cognate relation [21].

The contrast in grammatical functions between words with the original tone and its counterpart with derived departing tone can be attested in Old Chinese data. For example, the grammatical difference between the base verb and the derived verb 下 are illustrated in example sentences in (6).
(6) a. . 牛 羊下来
Niú yang xià ( ${ }^{c}$ yea) lái
cattle sheep go.down come
'...cattle and sheep have come down.'
(诗经王风君子于役 Shījīing Wángfēng Jūnzǐyúyì)

\author{
b. 其君 能下 人... \\ qí jūn néng xià $\left(\right.$ yea $\left.^{3}\right)$ rén \\ his king can lower people \\ 'The king humbled himself before his people'
}

(左传 宣公 12 年 Zuǒzhuàn Xuāng Gōng 12th Year)

In (6a) the base verb 下 is read in rising tone represented as $^{c} y e a$, and in this case it is an intransitive verb meaning 'go down', but when it is read in departing tone represented as $\mathrm{rea}^{\circ}$ in (6b) it becomes a transitive verb meaning 'cause to go down, lower' [21].

As in most cases of phonological derivation process the derived new word and the base word are represented by the same written form, and along the diachronic evolution of Chinese language its phonological system has greatly simplified, the similarity and difference between pairs of words with derivational relation are often blurred. However, phonological derivation process provides important evidence for understanding the lexical semantics of verbs in Old Chinese.

Another typological property of Old Chinese is that similar to Modern Chinese, Old Chinese also allows serial verb constructions, which can be defined as "a sentence that contains two or more verb phrases or clauses juxtaposed without any marker indicating what the relationship is between them."[29] In serial verb constructions in Old Chinese, verbs may be used in isolating positions with each verb having its independent argument configuration or in contiguous positions usually with two parallel verbs sharing a common argument structure. One example of the former case is given in (7a) and the latter in $(7 b)$.

\section{(7) a. 击李由军 破之。 \\ jī lǐ yóu jūn pò zhī.}

attack Li You army destroy it

'He attacked Li You's army and destroyed it.'

\section{(史记 曹相国世家 ShǐjiCáoxiàngguó shìjiā)}

\section{b. 陈余 击 走 常山王张耳。 chén yú jī zǒu cháng shān wáng zhāng èr Chen Yu attack run Changshan king Zhang Er 'Chen $\mathrm{Yu}$ attacked (and cause) Zhang Er the Changshan King to run.'}

\section{(史记张丞相列传 Shǐjì Zhāng Chéngxiàng lièzhuàn)}

In (7a) the verbs 击 $j \bar{l}$ 'attack' and 破 $p o$ 'destroy' are used in isolating positions, and each has its own objects. As long as the events described by these verbs happen in sequence logically almost any verb can be used in this construction. In (7b) the verbs 击 $j \bar{l}$ 'attack' and 走 zóu 'run' also co-occur in a single clause without any morphological marker, but they are used in contiguous positions sharing a common argument structure, i.e., both verbs take the subject 陈余 chén yú 'Chen Yu' and the object 常山王张耳 chángshān wáng zhāng èr 'Changshan 
King Zhang Er' as their own arguments. This kind of construction is also called parallel construct (Sun 2013). Note that though both types of constructions are considered serial verb constructions by $\mathrm{Li}$ and Thompson [29], they demonstrate different grammatical properties. The first type like (7a) may be bi-clausal expressing separate events. That is why the construction poses fewer constraints on types of verbs appearing in it. The second type like (7b) is generally considered mono-clausal, because it takes exactly two verbs which share all their arguments and cannot be separated by other elements. In particular, if the construction is modified by adverbs, both verbs are modified simultaneously [30]. This can be seen in (8)

(8) 尽 除去
jìn chú qù
completely remove get.rid.of
先 帝 之 故 臣
xiān dì zhī gù chén
former emperor Poss original vassal
'(He) completely replaced the former emperor's
original vassals...'

(史记 李斯列传 Shǐjì Lǐ Sī lièzhuàn)

In (8), the adverb 尽 jin 'completely' appears before both verbs 除 chú 'remove' and 去 qù 'get rid of' which form the serial verb constructions. It can neither be inserted between the two verbs nor can be understood as modifying only the former or the latter verb. Thus it is evident that the two verbs are used in a single clause.

The serial verb construction in Old Chinese and a careful distinction between different subtypes of this construction can help examine the lexical semantics of verbs in Old Chinese. It will be further explained as to the methodology and data in examining Old Chinese verbs.

\subsection{Motion Events Encoding in Old Chinese}

As to the typology of motion events, Old Chinese is believed to be a verb-framed language $[11,12,6]$. Its typological properties as verb-framed language can be attested from both its language structure and language use. As to language structure, different from Modern Chinese, the path of motion in Old Chinese is prototypically rendered into main verbs of the sentence as can be seen in (9). The path of the motion events are encoded into one-syllable verbs 入 rù 'enter' and 出 $c h \bar{u}$ 'exit' specifying the direction of motion.

(9) 姜入于室, 与 崔子自侧户出。 Jiāng rù yú shì yǔ cuīž̀ zì cè hù chū Jiang enter at room with Cuizi from side door exit

'Jiang entered the room and exited from the side door with Cuizi'

$$
\text { (左传 襄公 } 25 \text { 年 Zuǒzhuàn Xiāng Gōng 25th Year) }
$$

Concerning language use, Old Chinese is observed to have a larger path lexicon and path verbs are also used more frequently than manner verbs. Shi and $\mathrm{Wu}[10]$ in their study of six Old Chinese texts point out an obvious asymmetry towards path verbal constructions. The percentage of pure manner verbal constructions is about $11.17 \%$ of all motion constructions, but the percentage of pure path verbal constructions is about $74.53 \%$. Thus from the aspects of both language structure and language use, Old Chinese demonstrates typological features of the verb-framed languages. It is important to take the properties of this framing type of Old Chinese into account when the lexical semantics of verbs are examined.

\section{Research Methods and Data}

One of the most often used method to determine a verb's lexical semantics and grammatical behaviors in Modern Chinese, linguistic test, cannot be extended to Old Chinese, since Old Chinese is practically a dead language and the lexical semantics and grammatical behaviors of a verb in Old Chinese cannot be judged directly through native speakers' intuition, and in particular, negative evidence cannot be provided directly by linguistic tests. Though this problem makes the study of Old Chinese verbs more difficult, it is not impossible to reveal the properties of the lexicalization patterns of Old Chinese verbs. One way to investigate a verb's lexical semantics and grammatical behaviors in Old Chinese is to check its compatibility with other elements with certain grammatical features observed in data examples in authentic corpora. As to the study of manner or result verbs in motion events, it is indeed a plausible way. Levin and Rappaport Hovav [31] note that "the conceptual component which is lexicalized in the verb can be identified by determining which facet of the event the verb restricts." They further illustrate the point with the grammatical behaviors of English verbs. The verb 'move' can be used to describe the motion of any kind along any path in any kind of manner, because besides the meaning of motion itself the verb lexicalizes neither manner nor path information. Once a verb lexicalizes another conceptual component, the events that it can describe are accordingly restricted. If the verb lexicalizes the path, it imposes restrictions on the path of motion that can be described by the construction the verb is used in. Alternatively, if the verb lexicalizes a manner it necessarily restricts the manner, but not the path of the event it can be used to describe. Thus manner and path verbs show different compatibilities with other elements expressing manner and path in the same motion construction. For example, sentences in (10) with the English verbs enter and walk illustrates this point.

(10) a. John entered running/walking/jogging.

b. John walked into/out of/around the house.

As shown in (10a), enter necessarily expresses a path that ends in some space, but it does not restrict the manner 
of the motion, so it is compatible with different manner adverbials 'running', 'walking', and 'jogging'. In contrast, walk necessarily refers to a specific way of moving, but it does not imposes restrictions on the path of the motion, so it is compatible with a wide range of path information such as 'into, out of and around the house'. The same is also true for Old Chinese verbs. Based on authentic corpus of Old Chinese, checking the compatibility with other elements describing manner or path information, manner or path verbs can be identified in a reliable way.

However, there is a key difference between English and Old Chinese. In English, if one conceptual component of motion, manner or result, is expressed as the verb of the sentence, the other concept will be expressed outside the verb as adverbials, particles or prepositions, but Old Chinese, as discussed in Section 2, allows serial verb constructions, in which both components may be expressed as verbs at the same time. Thus it can be predicted that manner and path verbs in serial verb constructions must have different compatibility with other verbs expressing manner or path information. This makes it possible to determine a verb's ontological category. To be specific, I will determine the ontological category of Old Chinese verbs as manner or path by checking their distribution and compatibility with other verbs in serial verb constructions. Based on the properties of manner and path verbs discussed so far, I continue the study using the following criterion to determine the ontological category of motion verbs in Old Chinese data: only manner verbs are compatible with verbs expressing varied path information; only path verbs are compatible with verbs expressing varied manner information.

Note that the serial verb constructions used in present study are restricted to those describing a single integral motion event. If co-occurring verbs describe different motion events, in particular, as mentioned in Section 2, with respect to the situation where verbs are used in isolating positions, theoretically all verbs can co-occur in serial verb constructions, and then their compatibility have little to do with their lexical meaning. For example, in (11a) the two path verbs 出 $c h \bar{u}$ 'exit' and 归 $g u \bar{l}$ 'return' express two separate motion events which occur in sequence, i.e., the prince of Zhao firstly exited from the state of Qin and then he returned to his home state Zhao, so in spite of the fact that they lexicalize distinct directions of motion they can co-occur with each other in the serial verb construction without contradiction. Therefore, the target serial verb constructions I use are only restricted to those describing a single integral motion event as (11b).

\section{(11) a. 赵太子出 归国。 zhào tàiž̌ chū guī guó zhao prince exit return state \\ 'The prince of Zhao exited (from the state of Qin) and returned to his home state Zhao.'}

(史记 始皇本纪 Shǐjì Shǐ Huáng běnjì) b. 张耳 与赵王歇走入 巨鹿城。 zhāng ěr yŭ zhào wáng xiē zǒu rù jùlù chéng Zhang Er with ZhaoXie.king run enter Julu town 'Zhang Er and Zhao Xie the King ran into Julu town.'

$$
\begin{array}{r}
\text { (史记张耳陈余列传 Shǐjì Zhāng' Ěr Chén Yú } \\
\text { lièzhuàn) }
\end{array}
$$

In (11b) with the verb 入 rù 'enter' expressing the path and the verb 走 zŏu 'run' specifying the particular manner in which the whole event is executed, what they describe is just two accompanying parts of an integral event. In fact, only in this kind of serial constructions can the co-occurrence of components be accounted by the compatibility of their lexical semantics, since a single event cannot be carried out with two distinct manners or in two distinct directions.

In addition, whether a serial verb construction describes a single motion event can also be determined by the temporal contouring that the subevents involve. That is, if the subsevents described by the verbs in a serial construction occur within the same time contour, they are regarded as a single motion event, otherwise, they are not. For instance, in (11a), the two subevents described by the two verbs 出 $c h \bar{u}$ 'exit' and 归 guī 'return' do not occur within the same time span; rather they occur in sequence, so they are not regarded as a single event. In contrast, in (11b) the subevents described by the two verbs 走 zǒu 'run' and 入 rù 'enter' occur within the same time span; they unfold together, so they necessarily describe a single event.

The analysis presented in this part is based on attested data drawn from representative Chinese texts from Old Chinese period (BC 500-AD 200). The reasons why only texts from Old Chinese period are chosen are as follows. First, since the Chinese language has undergone radical changes since Old Chinese period, with most distinct typological features of verb-framed language $[12,6]$, lexical semantics and grammatical properties of motion verbs selected from texts composed in Old Chinese times must differentiate those in Modern Chinese to the largest degree, which will help check whether the MRC applies to a typologically different language. Second, to make the data more comparable to those in Modern Chinese, it is better to look at the lexicalization patterns of verbs within certain synchronic period, as data ranging a long period of history may not show consistent lexicalization features themselves. I have mainly examined the actual uses of motion verbs in two Old Chinese texts 左传 Zuǒzhuàn and 史记 Shǐjì, but when necessary, I also make reference to other texts composed in the same period of time. These texts include 论语 Lúnyǔ, 荀子 Xúnzi, 管子 Guănzi, 韩 非子 Hānfēizi，吕氏春秋 Lŭshì Chūnqiū and 战国策 Zhànguócè. All examples sentences mentioned in this part are from texts composed in Old Chinese period. I mainly get access to these texts via a diachronic corpus of Chinese texts named 汉籍全文检索系统 Hànjí Quánwén Jiănsuǒ Xitǒng developed by Shaanxi Normal University. With 
respect to the quoted example sentences, I have also looked up the hard copy texts to ensure the accuracy of those examples.

\section{Lexicalization Patterns of Motion Verbs in Old Chinese}

\subsection{Preliminary Classification of Motion Verbs in Old Chinese}

Focusing on 75 verbs collected by Ma [12] from six representative texts composed in Old Chinese period and with reference to her analysis of these verbs, I will first make a preliminary classification of these motion verbs. Ma classifies these verbs into three groups: manner verbs, path verbs and manner plus path verbs. Example verbs of each type are listed in (12).

(12) a. directed motion / path verbs:

\begin{tabular}{|c|c|}
\hline $\begin{array}{l}\text { 之 } z h \bar{l} \text { 'go', 入 rù 'enter', } \\
\text { 反 făn 'return', 至 } z h i ̀, \text { 'arrive' } \\
\text { 退 tuì 'retreat', 上 shàng, 'ascend' } \\
\text { 出 chū 'exit' }\end{array}$ & $\begin{array}{l}\text { 归 guī 'return', } \\
\text { 往 wăng 'go to', } \\
\text {, 下 xià, 'descend' }\end{array}$ \\
\hline $\begin{array}{l}\text { b. manner of motion verbs: } \\
\text { 驰 chí 'gallop', 迁 qiān 'move', } \\
\text { 游 yóu 'tour', 翔 xiáng 'fly', } \\
\text { 驱 qū 'drive (a horse, a cart, etc.) } \\
\text { c. manner + path verbs: }\end{array}$ & $\begin{array}{l}\text { 徙 xǐ‘move', } \\
\text { 旅 lǘ'travel', }\end{array}$ \\
\hline $\begin{array}{l}\text { zǒu 'run', 奔 bēn 'rush', } \\
\text { wáng 'flee', 济 jì ‘sail acros }\end{array}$ & \\
\hline
\end{tabular}

P29 [12]

In my analysis, I will first examine the verbs in (12a) and (12b) to see whether they conform to the MRC in terms of their lexical semantics and grammatical behaviors. Since $\mathrm{Ma}$ [12] claims that verbs in (12c) encode both manner and path meaning components, if she is correct, they will pose a real challenge for the MRC hypothesis, so following the analysis of the first two group of verbs, the verbs in (12c) will be analyzed in detail to see whether they indeed lexicalize the two components manner and path simultaneously violating the MRC hypothesis.

The result of the analysis of the first two groups of verbs in (12a) and (12b) indicates that their syntactic distributions show typical properties of manner and result verbs respectively. Verbs in (12a) are all manner verbs, so in Old Chinese data they are attested to co-occur with verbs expressing varied path information. Verbs in (12b) are all path verbs, they are found to appear with verbs describing different manners of motion. For example, the actual uses of the path verb 出 $c h \bar{u}$ 'exit' and manner verb 趋 $q \bar{u}$ 'hurry up' given in (13) and (14) illustrate this clearly.

$$
\begin{aligned}
& \text { (13) a.走 出, 遇 贼 于门。 } \\
& \text { zǒu chū yù zéi yú mén } \\
& \text { run exit meet rebel at gate }
\end{aligned}
$$

'(he) ran out and met rebels at the gate.'
(左传 庄公 8 年 Zuǒzhuàn Zhuāng Gōng 8th Year)

$$
\begin{aligned}
& \text { b.孔子 趋 出, 以 语子贡... } \\
& \text { kǒng zĩ qū chū yĩ yù zịgòng } \\
& \text { Confucius hurry.up exit with tell Zigong } \\
& \text { 'Confucius hurried out, and told (it) to Zigong...' }
\end{aligned}
$$

\section{(荀子 子道篇 Xúnzi Zǐdào piān)}

\author{
c.楚昭 王 亡 出 郢, 奔郧 \\ chǔzhāo wáng wáng chū yǐng bēn yún \\ Chuzhao king flee exit Ying rush Yun \\ 'Chuzhao the King fled from Ying and went to Yun'
}

$$
\text { (史记 吴太伯世家 Shǐjì Wú Tàibó shìjiā) }
$$

As can be seen from (13), the directed motion verb 出 $c h \bar{u}$ 'exit' only lexicalizes the path information without specifying the manner of motion in its lexical semantics, so it is compatible with a variety of verbs such as 走 zǒu 'run', 趋 qū 'hurry up' and 亡 wáng 'flee', which express different manners of motion.

In contrast, the manner verb 趋 $q \bar{u}$ 'hurry up' show different co-occurring properties with other verbs. It only lexicalizes the way how the motion is carried out, but does not specify direction of motion, so it is compatible with varied path verbs in serial verb constructions. As illustrated in (11), it may co-occur with varied path verbs such as 进 jin 'move forward', 过 guò 'pass', and 退 tui 'retreat'.

\section{(14) a. 王 孙贾 趋 进。}

Wángsūnjiă qū jìn

Wangssnjia hurry.up move.forward

'Wangsunjia hurried forward'

\section{(左传 定公 8 年 Zuǒzhuàn Dìng Gōng 8th Year)}

\author{
b. 公子 偃、公子 鉏 趋 过。 \\ gōngž̌ yăn gōngž̌ chú qū guò \\ Gongzi Yan Gongzi Chu hurry.up pass \\ 'Jiang got furious; Gongzi Yan and Gongzi Chu \\ hurried past.'
}

\section{(左传 成公 16 年 Zuǒzhuàn Chéng Gōng 16th Year)}

\author{
c. 申丰 趋 退 \\ shēnfēng qū tuì \\ shenfeng hurry.up recede \\ 'Shenfeng hurried backward.'
}

\section{(左传 襄公 23 年 Zuǒzhuàn Xiāng Gōng 23rd Year)}

Therefore, it is clear that based on their compatibility with different types of information, manner and path verbs in (12a) and (12b) show consistent grammatical behaviors with their counterparts in Modern Chinese, exhibiting distinct grammatical hallmarks of manner or result verbs. In serial verb constructions manner of motion verbs are compatible with varied path verb, while directed motion 
verbs can co-occur with different manner verbs. In next section, I will have a close look at the verb in (12c) to check whether they are counterexample verbs to the MRC.

\subsection{Purported Counterexamples to the MRC in Old Chinese}

Concerning the typological properties of motion events encoding in Old Chinese, following Slobin [5], researchers $[6,12]$ claim that as a typical verb-framed language, verbs encoding both manner and direction of motion in Old Chinese have systematic distributions. Ma [12] argues that besides the wide use of 'pure path verbs' in Old Chinese there are a group of manner of motion verbs which also have path implicitly encoded at the same time. Similarly, adopting a notion from Yang[32], Shi and $\mathrm{Wu}[6]$ calls this kind of verbs 'semantically synthetic verbs', since according to them these manner verbs encode path information as well. Some problematic verbs cited by these researchers are listed in (15).

(15) 走 zǒu 'run', 奔 bēn 'rush' 趋 qū 'hurry up' 逃 táo 'flee' 亡 wáng 'flee' 遁 dùn 'flee'

涉 shè 'sail across' 济 jì 'sail across'

The evidence used by Ma [12] and Shi and $\mathrm{Wu}$ [6] to support their argument is the same, i.e. without other path-indicating elements in the sentence these manner verbs can take noun phrases directly as their arguments to describe the direction of motion, as illustrated in (16).

(16) a. 怀王... 从 间道 走 赵...

huái wáng cóng jiāndào zǒu zhào

Huai king follow byway walk Zhao.State

'The King Huai went to the State of Zhao via a byway...'

\section{b. 王子 克 奔 燕。 \\ wángzǐ kè bēn yān}

Prince Ke rush Yan.State

'Prince Ke rushed to the State of Yan'

(左传 桓公 18 年 Zuǒzhuàn Huán Gōng 18th year)

$$
\begin{gathered}
\text { c.㚞於期 逃 秦 之燕。 } \\
\text { fán.yú qī táo qín zhī Yān }
\end{gathered}
$$

Fán.Yúqī flee Qin.State go Yan.State

'Hence in the past Fan.Yuqi fled from the State of Qin and went to the State of Yan'

(史记 鲁仲连邹阳列传 Shǐjì Lǔ Zhònglián Zōu Yáng lièzhuàn)

In (16), without other path-indicating elements in the sentence, the manner verbs 走 zŏu 'run', 奔 bèn 'rush' and 逃 táo 'flee' are all followed directly by noun phrases which indicate the direction of motion.

In addition, as observed by scholars[32,12] these verbs show clear contrast with other manner verbs (e.g. 行 xing 'move', 驰 chi 'gallop', 骋 chěng 'gallop'), which always need overt path-indicating elements to be expressed when they are used in motion events describing the direction of motion with reference to ground. For example, as shown in (17) when the manner verb 驰 chi 'gallop' is used in a motion construction where path information is also encoded, path verbs such as 往 wăng 'go to', 归 $g u \bar{\imath}$ 'return', 入 rù 'enter' etc. are needed to relate the manner verb 驰 chí 'gallop' to its ground information.

\section{(17) a. ...还 至 定陶，驰 入 齐王 壁} Huán zhì dìngtáo chí rù qí wáng bì return arrive Dingtao gallop enter Qi king barracks '(The king of Han) returned to Dingtao and galloped to the barracks of the King of Qi.'

\section{(史记 高祖本纪 Shǐjì Gāo Zǔ benji)}

b. 相如 乃 与 驰 归 成都。

xiàngrú năi yǔ chí guī Chéngdū

Xiangru hence with gallop return Chéngdū

'Xiangru then galloped back to Chengdu with (her).'

(史记 司马相如列传 Shřjì Sīmă Xiàngrú lièzhuàn)

c. 太子闻之, 驰 往...

tàiž̃ wén zhī chí wăng

Prince hear it gallop go.to

'The prince heard it. He galloped there...'

(史记 刺客列传 Shǐjì Cikè lièzhuăn)

However, there is an obvious problem with their analysis, i.e. the existence or non-existence of overt path-indicating elements in the sentence is not a reliable way to decide whether a verb encodes path or not. On the one hand, under certain circumstances overt path-indicating elements may be omitted due to varied reasons [13]. On the other hand, even with overt path-indicating elements the verb's ontological category cannot be determined simply, since not only manner verbs but also path verbs can be followed by path-indicating elements. For example, both of the verbs 入 rù 'enter' and 游 yóu 'tour' can be followed by the preposition 于 yú before they take noun phrases, but the two verbs belong to different ontological categories, as illustrated in (18).

\section{(18) a. 蔡侯 入于 糤邑 以 行}

cài hóu rù yú bì yì yǐ xíng

Cai Duke enter at my town in.order.to move

'Duke Cai entered my town in order to go (to State of Jin).'

\section{(左传 文公 17 年 Zuǒzhuàn Wén Gōng 17th Year)}

\section{b.卫侯 游 于 郊，子南仆}

wèi hóu yóu yú jiāo žnán pú

Wei duke tour yu suburb Zinan drive.a.cart

'Duke of Wei had Zinan drive a cart traveling around in the suburb.'

\section{(左传 哀公 2 年 Zuǒzhuàn Ai Gōng 2nd Year)}


In (18a) The verb 入 rù 'enter' is a pure path verb describing a directed motion as moving from outside to inside of a reference object, while in (18b) 游 yó u 'tour' is prototypical manner verb meaning 'travel or tour around'. Therefore, the existence or non-existence of the preposition 于 $y u$ in the sentence is not a reliable way to determine the ontological category of the verbs 入 rù 'enter' and 游 yóu 'tour'.

Thus in order to decide whether these verbs are indeed counterexamples to the MRC, a more careful investigation is needed. In the remainder of this section, I will look up the actual uses of these verbs in the corpus of Old Chinese trying to clarify their ontological category and find out whether they are counterexamples to the MRC. Based on their actual uses I suggest that these verbs actually lexicalize either manner or path in each use and thus conform to the MRC. Though these verbs seem to encode path and manner of motion, their manner and path information are derived from different sources, i.e. not both manner and path information are lexicalized in the verb itself simultaneously. To be specific, these verbs can be divided into 3 groups: (1) polysemous motion verbs with manner and path senses always encoded complementarily, (e.g. 走 zóu 'run', 奔 bēn 'rush', 趋 qu 'hurry up'), (2) manner verbs with path meaning component derived from the contexts (e.g 逃 táo 'escape', 亡 wáng 'escape' 遁 dùn 'escape') and (3) path verbs with manner meaning component derived from the contexts (e.g. 涉 shè 'sail across', 济 $j i$ 'sail across'). Generally, the grammatical behaviors of these verbs in Old Chinese corpus support this analysis. I will look at them group by group.

\subsubsection{Motion Verbs with Separate Manner or Result Sense 走 zŏu 'run', 奔 been 'rush', and 趋 qū 'hurry up'}

The primary lexical meaning of the verbs 走 zŏu 'run', 奔 bēn 'rush', and 趋 $q \bar{u}$ 'hurry up' in Old Chinese reflects the conceptualization of the manner of motion such as the gait or the speed of movement. An example sentence in which 走 zǒu 'run' specifying the manner of motion is provided in (19) below.

(19) 荀跞掩耳而走。

xún lì yăn ěr ér zǒu

Xun Li cover ears CONJ run

'Xun Li ran with his hands covering his ears.'

(左传 昭公 31 年 Zuǒzhuàn Zhāo Gōng 31st Year)

As in this case it only encodes the manner of motion, it is compatible with varied path information. As illustrated in (20), the verb 走 zóu 'run' is compatible with path information such as 反 făn 'return', 周 zhōu 'around' and 循 xún 'move along' to express varied directions of motion.

\footnotetext{
(20) a. 弃疾 使 周 走 而 呼

Qijí shǐ zhōu zǒu ér hū

Qiji cause around run CONJ shout

'Qiji made people run around and shout.'

(左传 昭公 13 年 Zuǒzhuàn Zhāo Gōng 13th Year)
}

\author{
b.循 墙 而 走... \\ xún qiáng ér zǒu \\ move.along wall CONJ run \\ '(I) ran along the wall...' \\ (左传 昭公 7 年 Zuǒzhuàn Zhāo Gōng 7th Year) \\ c.纣 反走 登鹿台 \\ zhòu făn zǒu dēng lùtái \\ Zhou.king return run mount Lutai \\ 'King Zhou ran back and mounted Lutai' \\ (史记 齐太公世家 Shǐjì Qí Tàigōng shìjiā)
}

Nevertheless, as mentioned above in Old Chinese these verbs may take locative nouns directly as their argument. Researchers $[12,6]$ take it as evidence that these verbs lexicalize both manner and path information of the motion. As can be seen in (21), the verb 走 zŏu 'run' can be immediately followed by locative nouns which act as the goal argument of the verb. Since there is no other element in the sentence to express the path information, the verb seems to encode both manner and direction of motion and thus constituting a counterexample to the MRC.

\section{(21) a. 齐侯 驾, 将 走 游棠}

qí hóu jià jiāng zǒu yóutáng

Qi duke ride.chariot will run Youtang

'The Duke of Qi rode a chariot and wanted to run to Youtang'

\section{(左传 襄公 18 年 Zuǒzhuàn Xiāng Gōng18th Year)}

\section{b. 百誉离居, 将 各走其邑}

băipú lí jū jiāng gè zǒu qí yì

Baipu scattered live will each run his town

'People of Baipu live in scattered communities and they would go back to their own town.'

\section{(左传 文公 16 年 Zuǒzhuàn Wén Gōng 16th year)}

Nonetheless, a careful analysis of 走 zǒu 'run' shows that when it takes a locative noun as its argument it does lexicalize the path of motion, but at the same time it also undergoes an ontological shift from a manner verb to a path one only lexicalizing the directed motion as 'go to'. There are mainly two pieces of evidence which support my argument.

First, when 走 zǒu 'run' is followed by a locative noun, it undergoes tone alternation to be read in the fourth tone class 去声 qùshēng 'departing tone', which can be regarded as a morphological marking of its categorical change. As discussed in 3.1, tone alternation is a productive way of word formation in Old Chinese. In his study of the tone alternation of words in Old Chinese, Sun [28] argues that words represented by the same Chinese character but differentiated by distinct tones should be treated as separate lexical entries with different lexical meanings. He analyzes 走 zǒu 'run' in detail and demonstrates that when lexicalizing the goal of the motion, the verb is always read 
in departing tone. The sentence pair in (22) illustrate the tone difference when 走 zǒu 'run' is used as a pure manner verb in (22a) or a path verb in (22b).

\section{（22）a. 荀跞 掩 耳而 走 xún lì yăn ěr ér zǒu ('tso) \\ Xun Li cover ears CONJ run \\ 'Xun Li ran with his hand covering his ears.'}

$$
\text { (左传 昭公 } 31 \text { 年 Zuǒzhuàn Zhāo Gōng 31st Year) }
$$

\section{b.赵斿 弃 车而走 林...}

zhào zhān qì chē ér zǒu $\left(\right.$ tso $\left.^{\circ}\right)$ lín

Zhao Zhan abandon cart CONJ run forest

'Zhao Zhan abandoned his cart and ran to the forest.'

\section{(左传 宣公 12 年 Zuǒzhuàn Xuān Gōng 12th year)}

In (22a), 走 zóu 'run' is used as a pure manner verb, it is read in rising tone, which is reconstructed in International Phonetic Alphabet as ${ }^{c} t s o$, but in (22b) when it is used as path verb followed by a locative noun, it is read in departing tone, which is represented as $t s o^{\circ}$. Because the alternation in the tone is consistent with its change in lexical semantics and syntactic distribution, the tone change can be regarded as morphological marking of its ontological shift.

Wang [33] also analyzes the semantic relation between pairs of motion verbs, which have derivational relation through tone change in Old Chinese. She argues that when read in departing tone, the originally boundless manner verbs like 走 zǒu 'run' 奔 bēn 'rush' and 趋 qū 'hurry up' become bounded motion verbs. In other words, the manner of motion verbs derive motion verbs with goal direction of 'go to' $[28,33]$ (Sun, 1997; Wang, 2013) by changing the phonetic feature of tone, which changes the motion from a boundless non-scalar change to a bounded two-point scalar change. As to the lexical features of manner and result verbs in general, though not all path verbs are bounded motion verbs (e.g. descend and ascend are boundless path verbs), bounded motion verbs are certainly path verbs, since manner verbs are aspectually unbounded and durative. While Sun [28] and Wang [33] do not state explicitly these verbs have undergone ontological category change from manner to path verbs via tone change, the difference in lexical meaning between the base verb and the derived verb which they note certainly confirms this fact.

Moreover, the fact that the verb 走 zŏu 'run' undergoes shift as to its ontological category can also be attested by its semantic entailment when it takes a locative noun directly. While the use of 走 zǒ $u$ 'run' as a manner verb always requires the theme to be animate, since it is a prototypical self-agentive motion verb describing the motion of human beings in particular, it is not necessarily the case for its use as path verb. Zhang[34] observes that when indicating the direction of motion, the action expressed by 走 zǒu 'run' is not restricted to any specific way of moving and it only describes a goal-directed motion. In Old Chinese texts the most often used goal argument of 走 zǒu 'run' is names of places or states such as 莒 $j u$ ' 'County Ju' 鲁 $l \check{u}$ 'the State of Lu', 秦 qin 'the State of Qin', etc.; the themes of the motion are very often people across all walks of life. Judging from the contexts, the involved manner of motion is not restricted to 'running using legs' or any specific type of motion. For instance, according to the contexts, the ways of motion involved in (23) are all different.

\section{(23) a. 齐侯 驾, 将 走 游棠 \\ qí hóu jià jiāng zǒu yóutang \\ Qi duke ride.chariot will run Youtang \\ 'The Duke of Qí rode a chariot and wanted to run to Youtang' \\ (左传 襄公 18 年 Zuǒzhuàn Xiāng Gōng18th Year)}

b. 长史 欣恐, 还 走 其军。 zhăng shǐ xīn kǒng huán zǒu qí jūn Zhangshi Xin scare return run his army 'Zhangshi Xin scared and returned to his army.'

\section{(史记 项羽本纪 Shǐji Xiàng Yǔ běnjì)}

\section{c. 始皇 三十七 年... 北 走 琅邪}

shǐ huáng sānshí qī nián běi zǒu lángyá

Emperor Shi thirty seventh year north run Langya

'In the thirty seventh year Emperor Shi... went in the north direction to Langya'

\section{(史记 蒙恬列传 Shǐjì Méng Tián lièzhuàn)}

In (23a) 齐侯 qi hóu 'the Duke of Qi' rode a chariot; in (23b) 长史欣 zhăngshì xīn 'Zhangshi Xin' probably rode a horse; and in (23c) 始皇 shǐ huáng 'Emperor Shi' probably traveled in a sedan chair. Thus it is clear that when used a directed motion verb 走 zǒu 'run' does not encode manner of motion.

Sun[28] (1997) also notes that when used in directed motion sense the subject of 走 zǒu 'run' can be inanimate, which provides further evidence for the dropping of manner sense in the lexical meaning of 走 zǒu 'run'. For example, as illustrated in (24a) the theme of 走 zóu 'run' is an inanimate entity 新丰道 Xìnfēng dào 'Xinfeng road', so in this case no manner sense can be possibly encoded at all.

\section{(24) a.上指示 慎夫人 新丰 道} shàng zhǐshì Shèn fürén Xīnfêng dào Emperor indicate Shen Madam Xinfeng road 曰: 此走邯郸 道也 yuē č̌zǒu Hándān dào yě say it run Handan road PART

'The emperor indicated Madam Shen and said, this road goes to Handan.'

(史记 张释之冯唐列传 Shìjì Zhāng Shìzhī Féng Táng lièzhuàn)

\footnotetext{
b...如 水之 走下

rú shuǐ zhī zǒu xià

like water POSS run down
} 
‘...like water's tendency of going down'

(管子 形势解 Guănzi Xíngshìjiě)

Similarly, in (24b), the theme of the motion is 水 shur 'water', so in this case no possible manner is encoded either. Unrestricted theme of the directed motion use of 走 zóu 'run' further confirms the fact that no manner is lexicalized in the verb.

To summarize, the actual uses of the verbs 走 zǒu 'run' 奔 been 'rush' and 趋 qū 'hurry up' in Old Chinese texts indicate that they are primarily manner of motion verbs, which are compatible with varied path information and only express the specific way in which the motion is carried out. However, when they are followed directly by noun phrases to indicate the goal of motion, their altered phonetic property and lexical entailment demonstrate that they undergo ontological shift from manner to path verbs. Therefore, they are not real challenge for the MRC hypothesis.

\subsubsection{Manner Verbs with Inferred Direction Sense: 逃 táo} 'flee', 亡 wáng 'flee', and 遁 dùn 'flee'

Another group of verbs which are said to encode both manner and path information simultaneously are 逃 táo 'flee', 亡 wáng 'flee', and 遁 dùn 'flee'. I argue, however, these three verbs are all manner verbs and their directed motion sense arises from the pragmatic support from the contexts. Though all of the three verbs can be translated as the English verb 'flee', they have distinct lexical meaning and grammatical behaviors from their counterpart in English. In Old Chinese, without prepositions or other path-indicating elements the three verbs can also take a locative noun as a reference object for the motion they specify. As shown in (25), the verb 逃 táo 'flee' takes the locative noun 秦 qin 'the State of Qin' directly without explicit path-indicating element in between.

(25) 焚於期 逃秦 之 燕。

fán yúqī táo qín zhī yān

FanYuqi flee Qin.state go Yan.state

'Fan Yuqi fled from the State of Qin and went to the State of Yan'

\section{(史记 鲁仲连邹阳列传 Shǐjì Lǔzhònglián Zōuyáng} lièzhuàn)

The same is true for the other two verbs 亡 wáng 'escape' and 遁 dùn 'escape', as they can also be followed by locative nouns immediately, as shown in (23)
(26) a. 汉兵 遁 保 巩...
hàn bīng dùn băogŏng
Han soldier flee Baogong.town
'Soldiers of Han fled to Baogong.'
(史记 䣓生陆贾列传 Lì Shēng Lù Jiă lièzhuàn)
b.伍子胥 之 亡 楚...
wǔ zǐxū zhī wáng chǔ

\section{Wu Zixu POSS flee Chu.state}

'Wu Zixu fled from the State of Chu...'

\section{(史记 刺客列传 ShǐJì Cìkè lièzhuăn)}

As to these cases, Lin [13] also argues that these verbs only lexicalize the manner of motion. She proposes that the locative nouns following these manner verbs may not be the arguments of these verbs; rather they may be the arguments of the omitted preposition 于/於 yú. She explains that in Old Chinese the preposition 于/於 yú may be omitted for varied reasons. She also presents different example sentences using the verb 逃 táo 'flee' in the texts composed in the same period with and without the preposition 于/於 $y u$, as illustrated in (24a) and (24b).

\section{(27) a. 伍子胥逃楚而之吴 wǔ žxū táo chǔ ér zhī wú} Wu zixu flee Chu.state CONJ go.to Wu.state 'Wu zixu fled from the State of Chu and then arrived at the State of Wu.'

$$
\text { (战国策 Zhànguócè, cited in [13] p 46) }
$$

$$
\begin{aligned}
& \text { b.桓 公 之 难, 管仲 逃 于 鲁 } \\
& \text { huán gōng zhī nán guănzhòng táo yú lŭ } \\
& \text { Huan.lord POSS difficulty Guanzhong flee to Lu } \\
& \text { 'When Lord Huan was in difficulty, Guan Zhong } \\
& \text { fled to the State of Lu' }
\end{aligned}
$$

$$
\text { (战国策 Zhànguócè, cited in [13] p 47) }
$$

However, there is a problem with Lin's analysis. If the locative noun is indeed the argument of an omitted preposition 于/於 $y u$, the direction of motion encoded by two kinds of verbal constructions, i.e., 逃 táo 'escape' is followed by 于/於 yú or not, should be the same. However, it is not the case. In (27a), when there is no preposition in between, the locative noun is the source of the motion, but in (27b) when there is the preposition 于/於 yú inserted, the locative noun is the goal of the motion. Thus Lin's argument that the locative noun is the argument of the omitted 于/於 yú does not hold.

I agree with Lin[13]) that 逃 táo 'flee', 亡 wáng 'flee' and 遁 dùn 'flee' only lexicalize the manner of motion, but I base this point on a different piece of evidence that these verbs are not associated with a consistent direction of motion, contrary to the hallmarks of path verbs. As manner verbs, when they take locative nouns directly, the direction of motion can only be inferred from the contexts. Depending on different contexts, 逃 táo 'flee' are compatible with different directions of motion, source or goal. As can be seen from (27a) above, the direction that the verb 逃 táo 'flee' is associated with is the source of motion, but in some other cases like (28), the locative noun is the goal of the motion.

(28) 使人 索扁鹊, 已逃秦 矣 shǐ rén suǒ biănquè yǐ táo qín yǐ make people seek Bianque already flee Qin PART 
'(Duke Huan) made people seek Bianque, but he had fled to the State of Qin.'

\section{(韩非子 喻老 Hánfēizi Yùlăo)}

In addition, in serial verb constructions 逃 táo 'flee' is also compatible with verbs encoding varied path information such as 归 $g u \bar{l}$ 'return', 来 lái 'come', etc. as seen in (29). This is also the evidence for the fact that 逃 táo 'flee' itself does not lexicalize direction of motion at all.

$$
\begin{aligned}
& \text { táo guī qí guó } \\
& \text { flee return his country }
\end{aligned}
$$

'...[he] fled back to his country...'

(左传 僖公 15 年 Zuǒzhuàn XīGōng 15th year)

$$
\begin{aligned}
& \text { b.秋，郑詹 自 齐 逃来。 } \\
& \text { qiū zhèng zhān zì qí táo lái }
\end{aligned}
$$

Autumn Zheng Zhan from Qi.State flee come

'In the autumn Zheng Zhan came fleeing from the State of Qi

$$
\text { (春秋公羊传 庄公 } 17 \text { 年 Chūnqiū Gōngyáng zhuàn }
$$$$
\text { Zhuāng Gōng 17th year) }
$$

In a summary, the problematic verbs such as 逃 táo 'flee', 亡 wáng 'flee', and 遁 dùn 'flee' are in fact manner verbs, because they do not impose restriction on path information they may co-occur with. When they are directly followed by locative nouns, the direction they encode can only be inferred from the contexts. Therefore, this group of verbs do not violate the lexical principle either.

\subsubsection{Directed Motion Verbs with Inferred Manner Sense 涉 shè 'sail across' and 济 $j i \imath$ 'sail across'}

Shi and $\mathrm{Wu}[6]$ cite 涉 shè 'sail across' and 济 jì 'sail across' as semantically synthetic verbs which are manner verbs but encode path information as well. Though they specify the path information encoded in the verb 涉 shè 'sail across' and 济 $j i$ 'sail across' as 'across', they do not explain what manner is encoded in these verbs exactly. I suggest that these verbs are actually directed motion verbs, and their manner sense is also inferred from the contexts.

For these two verbs 涉 shè 'sail across' and 济 $j i$ 'sail across', one may argue that besides the path information 'across', it also entails a motion in the medium of water which can be regarded as the manner of motion. However, I argue that the water medium cannot be regarded as manner information, and it is in fact the more elaborated path information of the motion. Concerning the properties of path lexicon of typologically different languages, Verkerk[35] argues that despite a limited set of abstract directions such as endpoint (enter), source (exit), mid-point (pass, cross), typologically different languages may differ as to how abstract or concrete they elaborate path of motion. While satellite-framed languages tend to have a limited set of abstract directions, verb-framed languages with relatively larger path lexicon tend to "have path verbs that refer to a far more varied set of more or less abstract reference points for motion placed within an environment" [35]. For instance, as she explains, Jahai, a Mon-Khmer language spoken in the Malay Peninsula, has verbs such as $r k r u k$ 'to move along the main river (in both upstream and downstream direction)', piris 'to move across the flow of water', dey 'to move upstream on a tributary' and hec 'to move downstream on a tributary' [36]. Though these verbs encode more elaborated path information, they are still path verbs. As a verb-framed language, Old Chinese also has relatively larger path lexicon including some directed motion verbs with more elaborated path information such as 涉 shè 'sail across' and 济 $j i$ 'sail across'. The medium of motion should be not regarded as a separate manner sense.

Nonetheless, path verbs with more salient and elaborated path information are not exclusive to verb-framed languages. For example, compared with other abstract path verbs such as descend and ascend in English, path verbs fall and sink not only lexicalize downward path with reference to the gravity, but also encode the medium the motion occurs within, air or water. In spite of this more elaborated path information, the ontological category of fall and sink is still that of path verbs, as their grammatical behaviors completely conform to hallmarks of result verbs, as illustrated in (30).

(30) a. ${ }^{*}$ The vase fell worthless.

b. *The sailors sank the boat useless.

c. The boat sank to the bottom of the river in 10 minutes.

d. The boat sank for 10 minutes

f. The leaves fell for / in a month.

As can be seen in (30a) and (30b), on the one hand, since they encode scalar changes, they cannot appear with a phrase denoting another scale. Though semantically it is plausible that as a result of its falling, a vase becomes worthless, the verb fall does not allow to be followed by the second predicate worthless. The same is true for sink, it does not allow another scale denoting predicate useless either. On the other hand, the changes they lexicalize involve multi-point scales, so they may be interpreted as atelic or telic based on the specific contexts exhibiting aspectual features typical to multi-point scalar changes as illustrated in (30c-f).

The two Old Chinese verbs 涉 shè 'sail across' and 济 jì 'sail across' can be analyzed in the same way. Though the medium of motion seem to be the manner of motion, it is in fact more elaborated path information, which can also be understood as adverbial modifier [37] of the motion, since they do not denote an independent change and do not affect the grammatical behaviors of the verbs. Therefore they are not counterexamples to the MRC either. 


\section{Conclusions}

As a prototypical verb-framed language, the lexicalization patterns of motion verbs in Old Chinese adhere to the MRC hypothesis. This confirms the validity and status of the MRC as a cross-linguistic lexical principle that constrains how much meaning a root can potentially lexicalize. It also supports the lexical semantic approach in the form of event structure decomposition as an effective way to reveal grammatical behaviors of verbs. However, languages may differ in strategies and morphosyntactic resources available to make up the lexicalization gap constrained by the lexical principle. Across languages, pragmatic inference from the contexts is a common strategy to fill the lexicalization gap. In addition, morphosyntactic resources available in typologically different languages may provide languages with language-specific devices to distinguish lexicon with different ontological categories. As discussed in this study, with more complicated phonological and morphological system, changing the phonetic properties of words in Old Chinese is one of the effective morphosyntactic devices facilitating verbs to derive a new separate sense and to distinguish manner and path sense from each other.

\section{REFERENCES}

[1] M. Rappaport Hovav, B. Levin. Building verb meanings. In M. Butt and W. Heuder (eds.), 97-134. The Projection of Arguments: Lexical and Compositional factors, Stanford, CA: CSLI Publications, 1998

[2] M. Rappaport Hovav, B. Levin. Reflections on manner/result complementarity. In E. Doron, M. Rappaport Hovav and I. Sichel (eds.), In Syntax, Lexical Semantics, and Event structure, 21-38. Oxford: Oxford University Press, 2010 .

[3] A. E. Goldberg. Verbs, constructions, and semantic frames, In E. Doron, M. Rappaport Hovav, and I. Sichel (eds.), Syntax Lexical Semantics, and Event Structure, Oxford, UK: Oxford University Press, 2010

[4] J.Beavers, , B. Levin, and S. W. Tham. Manner and result in the roots of verbal meaning. Linguistic Inquiry 43(3): 331-369, 2012.

[5] D. I. Slobin. The many ways to search for a frog: Linguistic typology and the expression of motion events. In S. Strömqvist and L. Verhoeven, (eds.), Relating Events in Narrative 2: Typological and Contextual Perspectives, 219-257. Mahwah, NJ: Lawrence Erlbaum, 2004

[6] W. L. Shi, Y. C. Wu. Evolution of motion representations in Chinese: Language structure, language use, and language typology. In J. X. Shen (ed.) Zhongguo Yuyanxue Youxiu Lunwenxuan. Berlin: De Gruyter Mouton, 2015

[7] L. Talmy. Toward a Cognitive Semantics, Volume II: Typology and Process in Concept Structuring. Cambridge MA: MIT Press, 2000
[8] L. Talmy. Lexicalization patterns: Semantic structure in lexical forms. In Timothy Shopen, (ed.), Language Typology and Syntactic Description 3: Grammatical Categories and the Lexicon, 57-149. Cambridge: Cambridge University Press, 1985

[9] C. Lamarre. The linguistic categorization of deictic direction in Chinese: With reference to Japanese. In Dan Xu (ed.) Space in Languages of China: Cross-linguistic, Synchronic and Diachronic Perspectives, 69-98. Dordrecht: Springer, 2008

[10] W. L. Shi, and Y. C. Wu. Which way to move: The evolution of motion expressions in Chinese. Linguistics. 52, (5): 1237-1292, 2014.

[11] A. Peyraube. Motion events in Chinese: A diachronic study of directional complements. In Maya Hickmann and Stéphane Robert (eds.), Space in Languages: Linguistic Systems and Cognitive Categories, 121-138. Amsterdam: John Benjamins, 2006.

[12] Y. X. Ma. Hanyu Lujing Dongci de Yanbian yu Weiyi Shijian de Biaoda [The Development of Chinese Path Verbs and Motion Event Expressions]. Beijing: Zhongyang Minzu Daxue Press, 2008.

[13] J. X. Lin. The Encoding of Motion Events in Chinese: Multi-morpheme Motion Constructions Ph. D. Dissertation, Stanford University, 2011.

[14] L. Qiu. The manner/result complementarity in Chinese motion verbs revisited. Proceedings of PACLIC 30, 2016.

[15] C. J. Fillmore. The grammar of hitting and breaking. In R. A. Jacobs, P. S. Rosenbaum. (eds.), Readings in English Transformational Grammar, 120-133. Waltham, MA: Ginn, 1970.

[16] C. Kennedy. Polar opposition and the ontology of "degrees". Linguistics and Philosophy, 24: 33-70, 2001.

[17] C. Kennedy, L. McNally. Scale structure and the semantic typology of gradable predicates. Language, 81(2): 345-381, 2005.

[18] M. Rappaport Hovav, B. Levin. Building scalar changes. In A. Alexiadou, H. Borer, and F. Achäfer, (eds.), The Syntax of Roots and the Roots of Syntax, 259-281. Oxford: Oxford University Press, 2014.

[19] L. Wang. Hanyu Shi Gao [An Outline of Chinese Language History]. Beijing: Zhonghua Shuju Press, 1980.

[20] X. L. Guo. Xianqin hanyu goucifa de fazhan [Development of word formation in Pre-Qin Chinese]. in Xiliang Guo (ed.), Hanyushi Lunji [Collected Essays in the History of Chinese], 131-152. Beijing: Shangwu Yinshuguan, 1997.

[21] J. L. Packard. A lexical phonology of Mandarin Chinese. In J. L. Packard (ed.), New Approaches to Chinese Word Formation: Morphology, Phonology, and the Lexicon in Modern and Ancient Chinese. 311-328. Berlin-New York: Mouton de Gruyter, 1998.

[22] G. B. Downer. Derivation by tone-change in classical Chinese, Bulletin of the School of Oriental and African Studies, 22(2): 258-290, 1959.

[23] F.-K. Chou. Ancient Chinese Grammar. Morphology Volume. [Zhongguo Gudai Yufa: Gouci Bian] Taipei, 
Taiwan: Tailian Guofeng Publishing Co, 1972.

[24] A. Schussler. The function of qusheng in Early Zhou Chinese. In Graham Thurgood, James A. Matisoff and David Bradley (eds.), 344-362. Pacific Linguistics Series C-No. 87. Canberra: The Australian National University, 1985.

[25] J. Norman. Chinese. Cambridge, UK: Cambridge University Press, 1988.

[26] W. H. Baxter. A Handbook of Old Chinese Phonology. Berlin-New York: Mouton de Gruyter, 1992.

[27] X. L. Guo. Hanzi Guyin Shouce [Handbook of Historical Pronunciation of Chinese Characters] Beijing: Peking University Press, 1986.

[28] Y. W. Sun. Hanyu Biandiao Gouci Yanjiu [Word formation through Tone Alternation in Classical Chinese]. Ph. D Dissertation. Peking University, 1997.

[29] C. N. Li, S. A. Thompson. Mandarin Chinese: A Functional Reference Grammar. Berkeley: University of California Press, 1981.

[30] J. McElvenny. The diachronic evolution of the directional particle lái in Mandarin. In R. Hendery, J. Hendriks (eds.) Grammatical Change: Theory and Description. Canberra: Australian National University Press, 2010.

[31] B. Levin, M. Rappaport Hovav. Lexicalization patterns. In R. Truswell (ed), Oxford Handbook of Event Structure,
Oxford UK: Oxford University Press, 2015

[32] R. X. Yang. Yuyi tezheng fenxi zai yufashi yanjiu zhong de zuoyong: you ' $\mathrm{V} 1+\mathrm{V} 2+\mathrm{O}$ ' xiang ' $\mathrm{V}+\mathrm{C}+\mathrm{O}$ ' yanbian zai tantao [The function of semantic feature ananlysis in the research of historical syntax: Evolution from ' $\mathrm{V} 1+\mathrm{V} 2+\mathrm{O}$ ' to ' $\mathrm{V}+\mathrm{C}+\mathrm{O}$ ' revisited] Beijing Daxue Xuebao [Journal of Peking Univeristy], 42 (2): 51-59, 2005.

[33] Y. T. Wang. Guhanyu zhong weiyi dongci de biandu wenti yanjiu [A study of phonetic changes of translational verbs in ancient Chinese: The types, conditions, rules and causes]. Yuyan Yanjiu [Studies in Language and Linguistics], 33(3): 73-86, 2013.

[34] Y. S. Zhang. Ciyu Dapei Bianhua Yanjiu: Yi Suiqian Ruogan Dongci yu Mingci de Dapei Bianhua Weili. [A Study of Word Collocation Evolution: Case Studies on Some Verbs and Nouns before Sui Dynasty]. Jinan, China: Qilu Shushe Chubanshe, 2005.

[35] A. Verkerk. The correlation between motion event encoding and path verb lexicon size in the Indo-European language family. Folia Linguistica Historica 35: 307-358, 2014.

[36] S. C. Levinson, N.Burenhult. Semplates: A new concept in lexical semantics? Language 85: 153-174, 2009

[37] M. Rappaport Hovav. Towards an understanding of the notions of 'manner' and 'result' and their role in the construction of verb meaning. In Roots Worshop, The Hebrew University of Jerusalem, 2015. 